\title{
EVALUATION OF ANTIDIABETIC ACTIVITY OF TRIDAX PROCUMBENS IN ALLOXAN INDUCED DIABETIC RATS
}

\author{
A Manga Devi' ${ }^{1}$ G Durga Madhuri², D. Narendra ${ }^{3}$ \\ ${ }^{1}$ Department of Pharmacology, VJ'S College of pharmacy, Rajahmundry, India. \\ ${ }^{2}$ Department of Pharmacology, VJ'S College of pharmacy, Rajahmundry, India. \\ *Corresponding author e-mail: manjuannamdevula@gmail.com
}

\begin{abstract}
:
Tridax procumbens have different medicinal properties due to its active phytochemical constituents and may able to treat diabetes \& diabetics complications. Tridax procumbens have wider range therapeutic advantages in proper management of a disease. Ethanolic extracts of Tridax procumbenswas prepared from plant parts are subjected to acute oral toxicity studies and found that the ethanolic extract of Tridax procumbensis safe to use up to the dose of $2000 \mathrm{mg} / \mathrm{kg}$. The ethanolic extract of Tridax procumbenswas found to be in dose dependent way against alloxan induced diabetes in rats. The reduction of the elevated blood glucose levels in diabetic rats on treatment with the extract at two different concentrations confirmed that ethanolic extract of Tridax procumbensposses Antidiabetic activity \& has shown significant effect when compared to Alloxan administration. It needs comprehensive investigations for developing a safe and effective herbal drug. Further research is required to isolate the biomolecules responsible for the antidiabetic and antidiabetic complications.
\end{abstract}

Key words: Tridax procumbens, ethanolic extracts, antidiabetic.

\section{INTRODUCTION:}

Diabetes mellitus is one of the most common endocrine diseases in all populations and all age groups. It is a syndrome of disturbed intermediary metabolism caused by inadequate insulin secretion or impaired insulin action, or both. Diabetes mellitus comprises of heterogeneous group of disorders characterized by hyperglycemia, altered metabolism of carbohydrates, lipids and proteins. Diabetes mellitus is associated with complications such as nephropathy, retinopathy, neuropathy and cardiovascular disease. ${ }^{1}$

Diabetes is mainly classified into three types as: Type-I (Insulin-Dependent Diabetes Mellitus, IDDM) and Type-II (Non- InsulinDependent Diabetes Mellitus, NIDDM), Type-
III (Gestational diabetes. Both these types are associated with excessive morbidity and mortality. Type I diabetes accounts for $5 \%$ to $10 \%$ of diabetes usually occurs in children or young adults. This disease is caused by autoimmune destruction of the pancreatic $\beta$ cells that secrete insulin. The process involves a smoldering destructive process that can persist for several years and ultimately leading to failure of insulin secretion. Patients with type I diabetes require insulin therapy for survival and most patients ultimately develop devastating complications of this disease. ${ }^{1}$ 


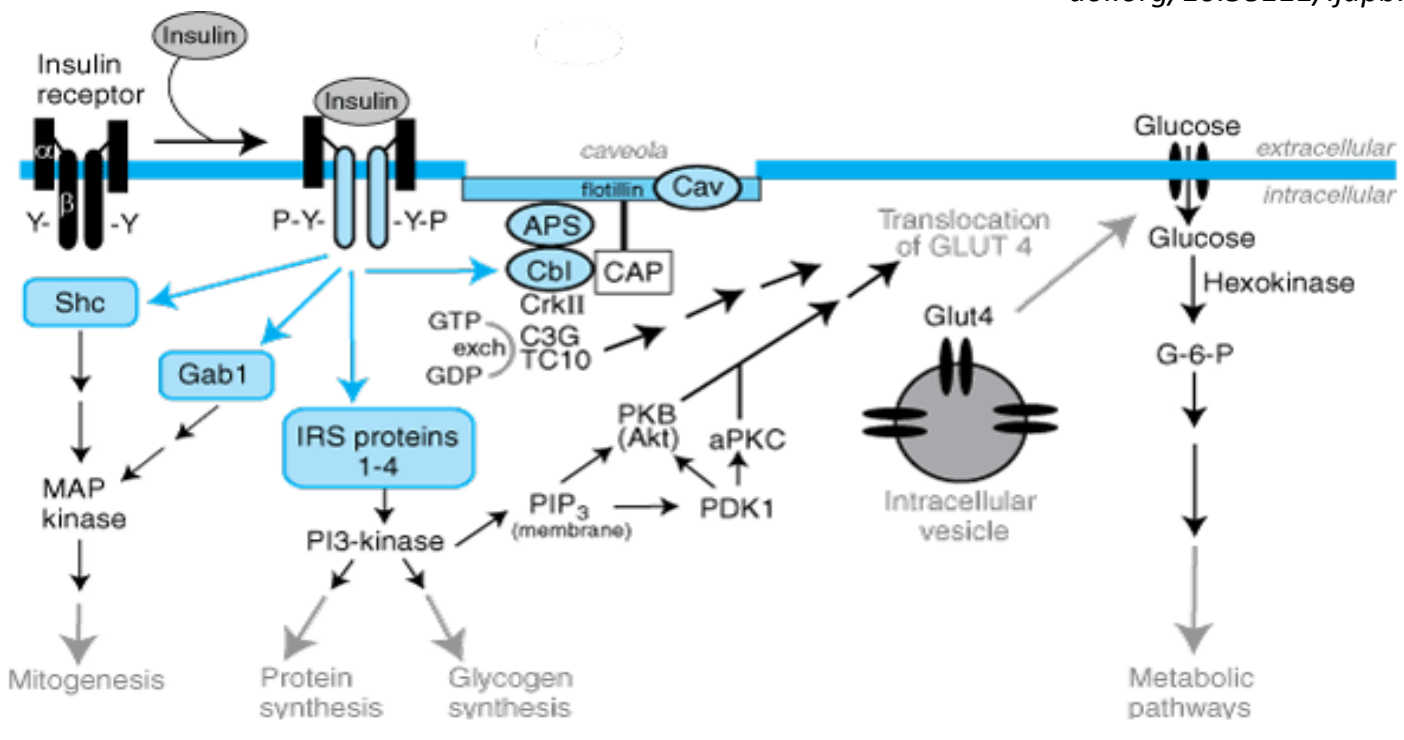

Figure 1: Pathways of insulin signaling2

Type II diabetes accounts for $90 \%$ to $95 \%$ of all patients with diabetes and is increasing in prevalence. Some of the known environmental factors that contribute to development of type-II diabetes are obesity, a sedentary lifestyle, and aging. Insulin resistance is a characteristic metabolic defect in the great majority of patients with type II diabetes. As a consequence of insulin resistance, the $\beta$-cell produces increased amounts of insulin, and, if sufficient, the compensatory hyperinsulinemia maintains glucose levels within the normal range.

In those individuals destined to develop diabetes, $\beta$-cell function eventually declines, and relative insulin insufficiency occurs. Thus, insulin resistance combined with $\beta$-cell failure leads to the decompensate hyperglycemic diabetic state.

Type-III diabetes is blood sugar elevation during pregnancy is called gestational diabetes. Diabetes can occur temporarily during pregnancy. Significant hormonal changes during pregnancy can lead to blood sugar elevation in genetically predisposed individuals. Gestational diabetes usually resolves once the baby is born.

\section{Treatment of Diabetes Mellitus}

Insulin therapy is required for all patients with type 1 Diabetes Mellitus and for those patients whose type 2 Diabetes Mellitus is not adequately controlled or is unresponsive to diet and oral medications. The goal of therapy is to maintain normal or near-normal blood glucose levels throughout the day. For type 2 Diabetes Mellitus, six classes of oral agents are available. ${ }^{3}$

Insulin is the primary hormone responsible for controlling the uptake, use, and storage of cellular nutrients. Insulin's anabolic actions include the stimulation of intracellular use and storage of glucose, amino acids, and fatty acids, whereas it inhibits catabolic processes such as the breakdown of glycogen, fat, and protein. It accomplishes these general purposes by stimulating the transport of substrates and ions into cells, promoting the translocation of proteins between cellular compartments, activating and inactivating specific enzymes, and changing the amounts of proteins by altering the rates of gene transcription and specific mRNA translation. 
Insulin stimulates stored glucose in the liver as glycogen and in adipose tissue as triglycerides and amino acid storage in muscle as protein; it also promotes utilization of glucose in muscle for energy. Insulin inhibits the breakdown of triglycerides, glycogen, and protein and the conversion of amino acids to glucose (gluconeogenesis). These pathways are increased during fasting and in diabetic states. The conversion of amino acids to glucose and of glucose to fatty acids occurs primarily in the liver as shown in figure 2 .

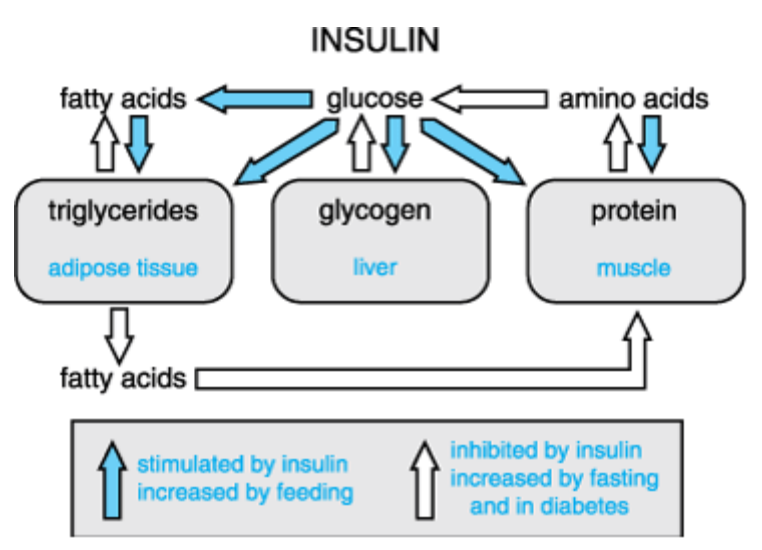

Figure 2: Overview of insulin action.

Sulfonylureas of $1^{\text {st }}$ generation drugs (Tolbutamide and chlorpropamide) and second generation drugs (Glibenclamide and Glipizide) main action is on B cells stimulate insulin secretion; their use also results in reduction of hepatic glucose production, reversal of the post-receptor defect, and increase in the number of insulin receptors.

Biguanides, such as Metformin, increase glucose uptake and utilization in skeletal muscle and reduce hepatic glucose production.

The nonsulfonylurea insulin secretagogues like repaglinide and nateglinide bind to a specific site on the sulfonylurea receptor and increase insulin secretion, although they are short-acting agents.
Thiazolidinediones, such as Pioglitazone and Rosiglitazone, bind to a nuclear receptor called peroxisome proliferators-activated receptor- $\gamma$ (PPAR-? ? which is complexed with retinoid $X$ receptor (RXR) increases lipogenesis and enhances uptake of fatty acids and glucose, decrease insulin resistance by enhancing insulin-mediated glucose disposal by muscle.

The $\alpha$-glucosidase inhibitors, such as acarbose and miglitol, block starch, sucrose and maltose absorption. ${ }^{3}$

\section{MATERIALS AND METHODS}

In this study subjects include ages of 10-80 years with both genders (Male \& Female) of population suffering from Hansen's disease.

\section{Cold Extraction (Ethanol Extraction)4:}

The Leaves of Tridax procumbens were collected and authenticated. The plant is grinded into a coarse powder with the help of suitable grinder. About 200gms of powdered material was taken in a clean, flat bottomed glass container and soaked in $750 \mathrm{ml}$ of ethanol. The container with its contents were sealed and kept for period of 7 days accompanied by continuous shaking with the shaker. The whole mixture then went under a coarse filtration by a piece of a clean, white cotton wool. The filtrates (ethanol extract) obtained were evaporated using Rotary evaporator in a porcelain dish. They rendered a gummy concentrate of greenish black. The extract was kept in vaccum desiccator for 7 days. \% Yield value of Ethanol Extract from Whole plant Parts of T. procumbens Plant is 26.77.

\section{Preliminary Phytochemical Screening}

Preliminary phytochemical screening of the Tridax procumbens extract was carried out for the analysis of Alkaloids, Carbohydrates, 
Tannins, Saponins, Steroids, Phenols and Flavonoids as per the standard methods. ${ }^{5}$

\section{Animals:}

Healthy Adult Male wistar rats of 8-10 weeks old with Average weight in the range of 150$180 \mathrm{gms}$ were selected. Animals are housed 4 per cage in temperature controlled $\left(27^{\circ} \mathrm{C} \pm 3\right.$ ${ }^{0} \mathrm{c}$ ) room with light/dark cycle in a ratio of 12:12 hrs is to be maintained. The Animals are allowed to acclimatize to the environment for seven days and are supplied with a standard diet and water ad libitum. The prior permission was sought from the Institutional Animal Ethics Committee (IAEC) for conducting the study.

\section{Acute toxicity studies}

The Acute oral toxicity test of the extracts was determined prior to the experimentation on animals according to the OECD (Organization for Economic Co-operation and Development) guidelines no 423. Female Albino wistar rats were taken for the study and dosed once with $2000 \mathrm{mg} / \mathrm{kg}$ of the extract. The treated animals were monitored for 14 days to observe general clinical signs and symptoms as well as mortality. No mortality was observed till the end of the study revealing the $2000 \mathrm{mg} / \mathrm{kg}$ dose to be safe. Thus, $1 / 10$ and $1 / 20$ doses of 2000 $\mathrm{mg} / \mathrm{kg}$ i.e. $100 \mathrm{mg} / \mathrm{kg}$ and $200 \mathrm{mg} / \mathrm{kg}$ were chosen for subsequent experimentation.

\section{Induction of diabetes}

Diabetes mellitus or hyperglycemia was induced in rats by administration of alloxan monohydrate $\quad(2,4,5,6$-tetraoxypyrimidine; 2,4,5,6-primidinetetrone) at dose of $120 \mathrm{mg} / \mathrm{kg}$ intraperitoneally in normal saline. After one hour of alloxan administration the animals were given feed ad libitum. The animals were kept fasting overnight and blood glucose levels were estimated before and after $72 \mathrm{hrs}$ of alloxan treatment. Animals showing blood glucose levels of $>200 \mathrm{mg} / \mathrm{dl}$ is considered as diabetic and were used for study.

\section{Experimental Study Design}

Diabetic rats were divided in to five groups with four animals each.

Group-I: rats served as normal control group Group-II: served as diabetic/disease control. Group-III: Diabetic rats treated with Tridax procumbens plant extract at a dose $120 \mathrm{mg} / \mathrm{kg}$ (low dose).

Group-IV: Diabetic rats treated with Tridax procumbens plant extract at a dose of $200 \mathrm{mg} / \mathrm{kg}$ (high dose).

Group V: Diabetic rats treated with Metformin (standard drug) at $450 \mathrm{mg} / \mathrm{kg}$.

The treatment was given for 14days and blood samples were collected at different intervals.

\section{Waste disposal}

Wastage will be removed regularly and frequently in a safe and sanitary manner and will be incinerated, animal tissues,carcusses also incinerated if they have to be stored they will be packed in a leak proof plastic bag and stored in required temperature avoiding decomposition and contamination, if hazardous chemicles used first they are neutralized and disposed.

\section{Glucose Method: GOD/POD method:}

Wavelength/filter: $505 \mathrm{~nm}$

Temperature: $37^{\circ} \mathrm{C} /$ R.T.

Light path : $1 \mathrm{~cm}$

Pipette into clean dry test tubes labeled as Blank (B), Standard (S) and Test (T)

\begin{tabular}{|l|c|c|c|}
\hline $\begin{array}{l}\text { Addition } \\
\text { Sequence }\end{array}$ & B (ml) & S (ml) & T (ml) \\
\hline $\begin{array}{l}\text { Glucose } \\
\text { Reagent L1 }\end{array}$ & 1.0 & 1.0 & 1.0 \\
\hline $\begin{array}{l}\text { Distilled } \\
\text { Water }\end{array}$ & 0.01 & -- & -- \\
\hline $\begin{array}{l}\text { Glucose } \\
\text { Standard S) }\end{array}$ & -- & 0.01 & -- \\
\hline Sample & -- & -- & 0.01 \\
\hline
\end{tabular}


Mix well and incubate at $37^{\circ} \mathrm{C}$ for $10 \mathrm{~min}$ or at R.T. $\left(25^{\circ} \mathrm{C}\right)$ for 30 mins. Measure absorbance's of the Standard (Abs.S) and Test Sample (Abs.T) compare these against the Blank within 60 mins.

\section{Statistical Analysis}

All the values will be expressed as mean \pm S.D. Statistical comparisons between different groups will be done by using one-way analysis of variance. $\mathrm{P}$ value $<0.05$ will be considered as statistically significant.

\section{RESULTS}

\%Yield of ethanolic Extract from Aerial Parts of Tridax procumbens was found to be $26.77 \%$.

\section{Preliminary Phytochemical Screening}

Investigation revealed the presence of Alkaloid, Tannin, Saponin, Phenol in Ethanolic Extract of Tridax procumbens while only Phenol were present in Phenolic Extract of Tridax procumbens

Table. 1 Preliminary Phytochemical Screening [(+) Present; (-) Absent]

\begin{tabular}{|c|c|}
\hline Phytochemical & Results \\
\hline Steroid & - \\
\hline Alkaloid & + \\
\hline Tannin & + \\
\hline Carbohydrate & - \\
\hline Phenol & + \\
\hline Flavonoid & + \\
\hline Saponin & + \\
\hline
\end{tabular}

Acute toxicity studies

As per (OECD) draft guidelines 423 adopted, male wistar rats were administered with Tridax procumbens and doses was be selected in the sequence (1.75- 5000) using the default dose progression factor, for the purpose of toxicity study. Animals are observed individually at least once during the first 30 minutes after dosing, periodically during the first 24 hours and daily thereafter, for a total of 14 days,. In all the cases, no death was observed within 14 days. Additional observations like behavioral changes in skin, fur, eyes, mucous membranes, respiratory, circulatory, autonomic and central nervous systems and somato motor activity and behavior pattern were also found to be normal. Attention was also given to observation of tremors and convulsions, salivation, diarrhoea, lethargy, sleep and coma.

\begin{tabular}{|c|c|c|c|}
\hline \multicolumn{4}{|c|}{\begin{tabular}{|c|}
$\begin{array}{c}\text { Table: Effect of Tridax procumbens (EETP)on serum } \\
\text { glucose levels (mg/dl) in diabetic rats }\end{array}$ \\
\end{tabular}} \\
\hline Groups/Interval & 1 $0^{\text {th }}$ Day & $7^{\text {th }}$ Day & $15^{\text {th }}$ Day \\
\hline Normal & $83.3 \pm 4.23$ & $79.1 \pm 5.36$ & $77.7 \pm 5.62$ \\
\hline Diabetic control & $283.8 \pm 5.01$ & $286.4 \pm 12.4$ & $300.3 \pm 8.64$ \\
\hline $\begin{array}{c}\text { EETP } \\
(50 \mathrm{mg} / \mathrm{kg})\end{array}$ & $293.1 \pm 9.83$ & $192.1 \pm 12.3^{* *}$ & 100.3 \\
\hline $\begin{array}{c}\text { EETP } \\
(100 \mathrm{mg} / \mathrm{kg})\end{array}$ & $280.5 \pm 42.4$ & $185.2 \pm 11.2^{* * *}$ & $94.2 \pm 7.2^{* * *}$ \\
\hline $\begin{array}{l}\text { Metformin } \\
(450 \mathrm{mg} / \mathrm{kg})\end{array}$ & $271.0 \pm 13.5$ & $80.2 \pm 6.4^{* * *}$ & $70.1 \pm 6.3^{* *}$ \\
\hline काष & , & $l$. & ** \\
\hline
\end{tabular}

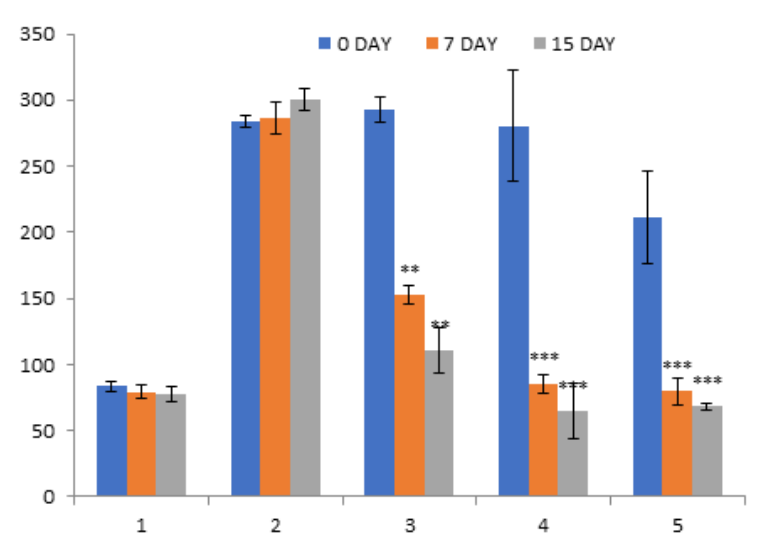

Figure: Effect of EETP on serum glucose levels (mg/dl) in diabetic rats

\section{Histopathological studies}

The histopathological observations of the rat kidneys revealed that the normal control group rats shows normal glomeruli and kidney tubules with healthy epithelial cells. The kidneys of diabetic control group rats shows thickening of vesicles disrupted tubules, degeneration and necrosis of epithelial cells and intertubular haemorrhage. But the kidneys of diabetic rats treated with EETP (120mg/kg) and EETP (200mg/kg) 
showed regeneration of tubular epithelium depicting normal tubules with intact epithelium and presence of few RBCs in between tubules.

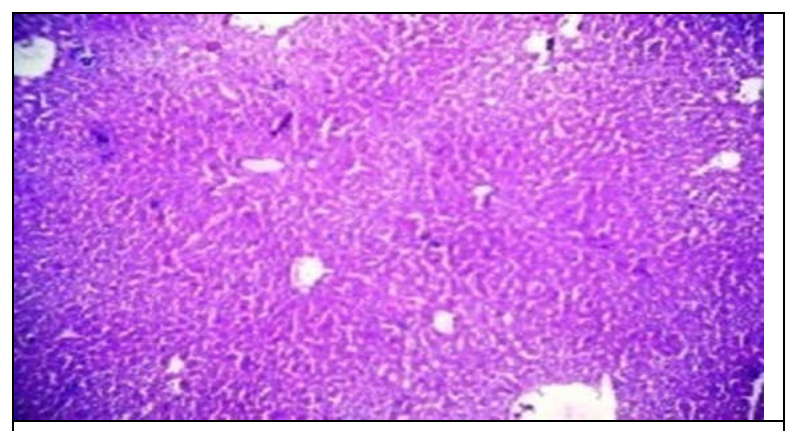

Figure: Normal rats treated with 1\% W/V CMC in water $10 \mathrm{ml} / \mathrm{kg}$ (HE $100 \mathrm{X}$ )

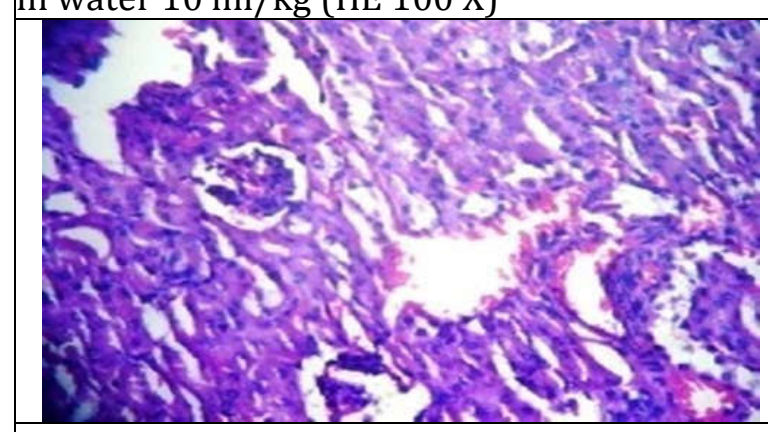

Figure: Diabetic rats treated with $1 \% \mathrm{~W} / \mathrm{V}$

CMC in water $100 \mathrm{ml} / \mathrm{kg}$ (HE 100X)

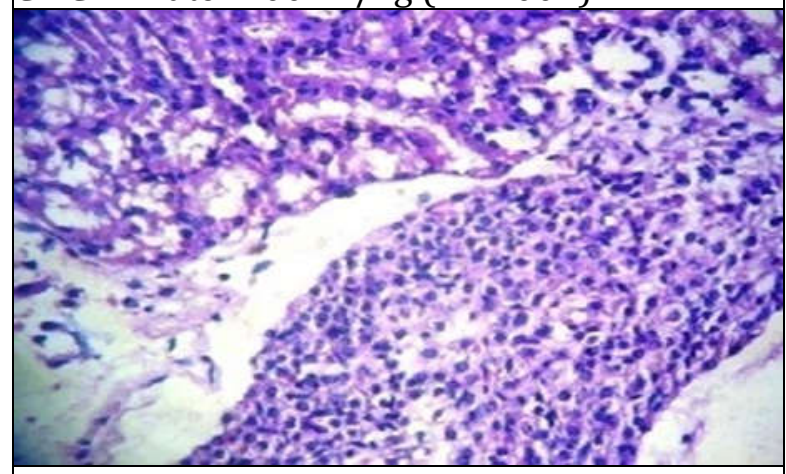

Figure: Diabetic rats treated with EETP (120mg/kg) (HE $100 \mathrm{X}$ )

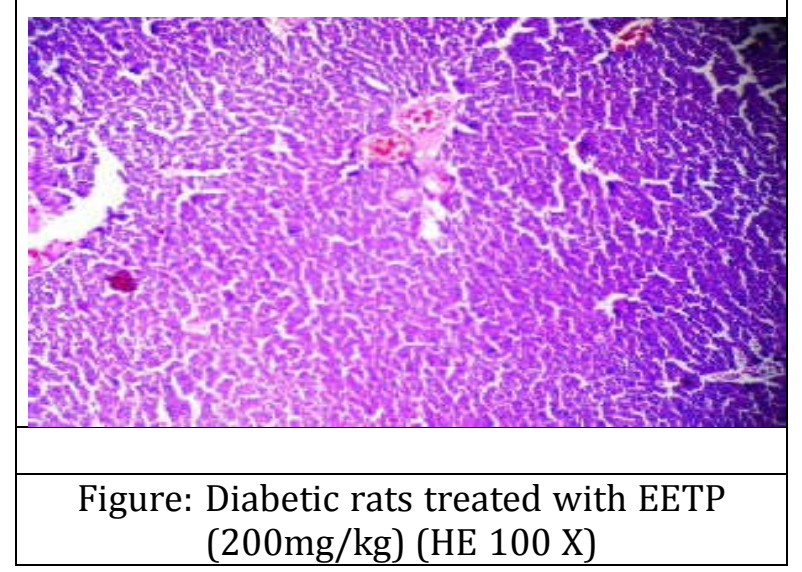

www.ijapbjournal.com doi.org/10.38111/ijapb.20160204002

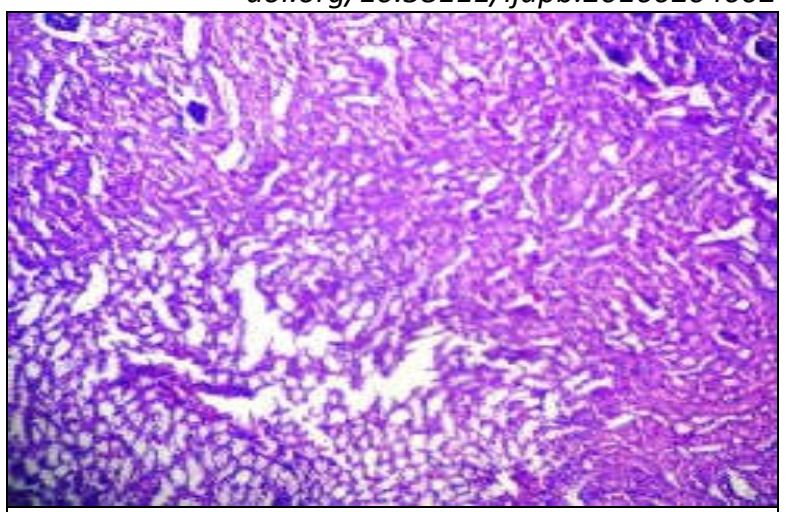

Figure : Diabetic rats treated with Metformin $(450 \mathrm{mg} / \mathrm{kg})(\mathrm{HE} 100 \mathrm{X})$

\section{DISCUSSION}

The present study was aimed to evaluate the anti diabetic, of Tridax procumbens. The activity was measured by estimating various biomarkers like blood glucose levels, in experimental rats. In the previous studies it was shown that alloxan induced to diabetes mellitus. When given in a dose of $120 \mathrm{mg} / \mathrm{kg}$ to rats intraperitoneally as evidenced in study. ${ }^{23}$ In the present study alloxan was administered in a single dose to induce diabetes mellitus in rats at the dose of $120 \mathrm{mg} / \mathrm{kg}$. The Tridax procumbenshas reported anti-microbial properties but the effect of the plant extract on antidiabetic, were not reported yet and so the plant was chosen for the study. Alloxan forms an increased glucose levels that generates diabetes. Pretreatment with Tridax procumbensproduced significant decrease in glucose levels indicating the protective effect of tissue. On alloxan treatment a dose dependent decrease in glucose levels were observed. Pretreatment with Tridax procumbensand metformin produced significant alteration in levels.

\section{CONCLUSION}

Tridax procumbens have different medicinal properties and may able to treat diabetes \& diabetics complications. Subjected to acute oral toxicity studies and found that the Tridax

IJAPB 


\begin{tabular}{|c|c|c|c|c|c|c|c|c|c|}
\hline \multicolumn{10}{|c|}{ Table: Acute toxicity study of Tridax procumbens EETP $(120 \mathrm{mg} / \mathrm{kg})$ on Wistar Rat } \\
\hline EFFECTS & RESPONSE & 5 MINS & $\begin{array}{c}30 \\
\text { MINS }\end{array}$ & 1 HR & 2 HRS & 24 HRS & 48 HRS & 7 DAYS & $\begin{array}{c}14 \\
\text { DAYS }\end{array}$ \\
\hline Breathing & Normal/Fast/Slow & Normal & Normal & Normal & Normal & Normal & Normal & Normal & Normal \\
\hline $\begin{array}{c}\text { Paralytic } \\
\text { effects of hind } \\
\text { limbs }\end{array}$ & No/Yes & No & No & No & No & No & No & No & No \\
\hline Passivity & No/Yes & No & No & No & No & No & No & No & No \\
\hline Grip & $\begin{array}{c}\text { Normal/Strong/ } \\
\text { Weak }\end{array}$ & Normal & Normal & Normal & Normal & Normal & Normal & Normal & Normal \\
\hline Salivation & No/Yes & No & No & No & No & No & No & No & No \\
\hline Climbing slide & No/Yes & Yes & Yes & Yes & Yes & Yes & Yes & Yes & Yes \\
\hline Sense & Normal/Senseless & Normal & Normal & Normal & Normal & Normal & Normal & Normal & Normal \\
\hline Over activity & No/Yes & No & No & No & No & No & No & No & No \\
\hline Aggressiveness & No/Yes & No & No & No & No & No & No & No & No \\
\hline Fits & No/Yes & No & No & No & No & No & No & No & No \\
\hline $\begin{array}{l}\text { Touch } \\
\text { response }\end{array}$ & Normal Pain & Normal & Normal & Normal & Normal & Normal & Normal & Normal & Normal \\
\hline Allergy & $\begin{array}{c}\text { No allergy } \\
\text { Redness/Swelling }\end{array}$ & No & No & No & No & No & No & No & No \\
\hline Died & No/Yes & No & No & No & No & No & No & No & No \\
\hline & 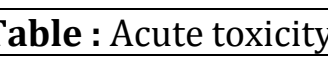 & & idaxp & en & & $/ \mathrm{kg}$ & vista & & \\
\hline EFFECTS & RESPONSE & 5 MINS & $\begin{array}{c}30 \\
\text { MINS }\end{array}$ & $1 \mathrm{HR}$ & 2 HRS & $\begin{array}{c}24 \\
\text { HRS }\end{array}$ & $\begin{array}{c}48 \\
\text { HRS }\end{array}$ & $\begin{array}{c}7 \\
\text { DAYS }\end{array}$ & $\begin{array}{c}14 \\
\text { DAYS }\end{array}$ \\
\hline Breathing & Normal/Fast/Slow & Normal & Normal & Normal & Normal & Normal & Normal & Normal & Normal \\
\hline $\begin{array}{c}\text { Paralytic } \\
\text { effects of hind } \\
\text { limbs }\end{array}$ & No/Yes & No & No & No & No & No & No & No & No \\
\hline Passivity & No/Yes & No & No & No & No & No & No & No & No \\
\hline Grip & $\begin{array}{c}\text { Normal/Strong/ } \\
\text { Weak }\end{array}$ & Normal & Normal & Normal & Normal & Normal & Normal & Normal & Normal \\
\hline Salivation & No/Yes & No & No & No & No & No & No & No & No \\
\hline Climbing slide & No/Yes & Yes & Yes & Yes & Yes & Yes & Yes & Yes & Yes \\
\hline Sense & Normal/Senseless & Normal & Normal & Normal & Normal & Normal & Normal & Normal & Normal \\
\hline Over activity & No/Yes & No & No & No & No & No & No & No & No \\
\hline Aggressiveness & No/Yes & No & No & No & No & No & No & No & No \\
\hline Fits & No/Yes & No & No & No & No & No & No & No & No \\
\hline $\begin{array}{l}\text { Touch } \\
\text { response }\end{array}$ & Normal Pain & Normal & Normal & Normal & Normal & Normal & Normal & Normal & Normal \\
\hline Allergy & $\begin{array}{c}\text { No allergy } \\
\text { Redness/Swelling }\end{array}$ & No & No & No & No & No & No & No & No \\
\hline Died & No/Yes & No & No & No & No & No & No & No & No \\
\hline
\end{tabular}

procumbens was safe to use up to the dose of $2000 \mathrm{mg} / \mathrm{kg}$. The Tridax procumbens was found to be in dose dependent way against alloxan induced diabetes in rats. The reduction of the elevated blood glucose levels in diabetic rats on treatment with the extract at two different concentrations confirmed that ethanolic extract of Tridax procumbens posses Antidiabetic activity \& has shown significant effect when compared to alloxan administration. It needs comprehensive 
Manga Devi A et al.

investigations for developing a safe and effective drug. Further research is required to confirm the antidiabetic and antidiabetic complications.

\section{ACKNOWLEDGEMENT}

Our sincere gratitude to each and every pharma fraternities, colleagues and friends who supported us throughout work and lead us towards successful completion of this research.

\section{CONFLICT OF INTEREST}

The author(s) confirm that this article content has no conflict of interest.

\section{REFERENCES}

[1] T.Sundar Rajan, Vijey Aanandhi M Antidiabetic Activity Of Ethanolic Extract Of Alternanthera Ficodia Linn In Streptozotocin Induced Diabetic Rats Int J Pharm Bio Sci 2016 July ; 7(3): (P) 177 180.
Int. J. Adv. Pharm. Biotech., 2016; 2(4): 7-14 doi.org/10.38111/ijapb.20160204002

[2] Mrinmay Das, Ashok Kumar D , Mastanaiah K and Arup Das Evaluation of Anti-diabetic Activity of Ethanolic Extract of Alternanthera sessilis Linn. in Streptozotocin-induced Diabetic rats. IJPSR Vol. 6 No.7 Jul 2015.

[3] Sabbani.Vidya , A.Ramesh , S.Shobharani Evaluation of anti-diabetic activty of ethanolic and methanolic extracts of leaves of curcuma inodora against streptozotocin induced diabetic rats IOSR Journal of Pharmacy and Biological Sciences 9(5)2014, 45-49.

[4] American diabetes association: Nephropathy in diabetes. Diabetes care, 27, 2004, S79-S82.

[5] Chaney,A.L. and Marbach. Urea (Berthelot method) Clin. chem. 1962; 8;130.

\section{How to cite this article:}

A Manga Devi et al., Evaluation Of Antidiabetic Activity Of Tridax Procumbens In Alloxan Induced Diabetic Rats. Int. J. Adv. Pharm. Biotech., Int. J. Adv. Pharm. Biotech., 2016; 2(4): 7-14. 